\title{
AN IMPROVED METHOD FOR GENOTYPING OF $N$-ACETYLTRANSFERASE POLYMORPHISM BY POLYMERASE CHAIN REACTION
}

\author{
Masako ABE, ${ }^{1, *}$ Tomokazu Suzuki, ${ }^{1}$ and Takeo DeGuchI ${ }^{2}$ \\ ${ }^{1}$ Department of Clinical Genetics, Medical Institute of Bioregulation, Kyushu University, \\ Tsurumihara, Beppu, Oita 874, Japan \\ ${ }^{2}$ Department of Molecular Neurobiology, Tokyo Metropolitan Institute for Neurosciences, \\ Musashidai, Fuchu, Tokyo 183, Japan
}

\begin{abstract}
Summary Polymorphic $\mathrm{N}$-acetyltransferase in human liver catalyzes $\mathrm{N}$-acetylation of various arylamine-containing drugs and environmental chemicals. To accelerate the pharmacogenetic and ecogenetic studies of $\mathrm{N}$-acetyltransferase polymorphism, we have developed a rapid and simple method for genotyping using a polymerase chain reaction based restriction fragment length polymorphism. This method distinguishes four kinds of allele of the $N$-acetyltransferase gene using a single polymerase chain reaction starting with a set of primers, followed by successive Asp 718, BamHI and TaqI digestions, and then running the samples on a single electrophoresis lane. This method allows us to determine ten different genotypes easily and reliably.
\end{abstract}

Key Words genotype, $N$-acetyltransferase, polymorphism, polymerase chain reaction

\section{INTRODUCTION}

$N$-Acetylation polymorphism is one of the most extensively studied pharmacogenetic traits (Weber and Hein, 1985; Evans, 1989). This polymorphism is caused by polymorphic $N$-acetyltransferase (NAT2) that catalyzes the $N$-acetylation of various arylamines and hydrazines. The enzyme is expressed in liver and distinguishable by its substrate specificity from the monomorphic $N$-acetyltransferase (NAT1) (Ohsako and Deguchi, 1990; Grant et al., 1991). N-Acetylation polymorphism is related to drug toxicity and it is supposed to be associated with the susceptibility to colorectal cancer (Lang et al., 1986; Ilett et al., 1987) and urinary

Received December 8, 1992; Revised Accepted January 18, 1993.

*To whom correspondence should be addressed. 
bladder cancer (Mommsen and Aagaard, 1986). NAT2 is produced by a single gene called NAT2 (Ohsako and Deguchi, 1990; Blum et al., 1990). We have found one 'rapid' human $N A T 2$ allele (allele 1) which produces the high activity enzyme, and two 'slow' alleles (allele 2 and 3 ) which produce the low activity enzymes (Deguchi et al., 1990). Three NAT2 phenotypes i.e. slow, intermediate, and rapid acetylators were correlated with five genotypes generated by combinations of the 3 alleles (Deguchi et al., 1990). Recently we showed that another allele which has no KpnI site (Hickman and Sim, 1991; Blum et al., 1991; Vatsis et al., 1991) also exists among the Japanese, and is designated as allele 4 (Mashimo et al., 1992). Subsequent study revealed that this allele has the same three nucleotide substitutions i.e. nt (nucleotide position according to Ohsako and Deguchi (1990)) 341, 481, and 803 as $\mathrm{r}_{3}$ reported recently by Vatsis et al. (1991) (manuscript in preparation). Allele 4 is referred to as a 'slow' type allele (Vatsis et al., 1991). Consequently $\mathrm{N}$ acetylator phenotypes can be predicted by determining which combination of the 4 known alleles an individual has. Blum et al. (1991) and Hickman and Sim (1991) have reported different methods for genotyping the NAT2 using polymerase chain reaction (PCR). However those methods not only seemed to be cumbersome, but also time consuming. In this paper, we describe an improved rapid and simple genotyping method using a PCR-based restriction fragment length polymorphism (RFLP).

\section{MATERIALS AND METHODS}

Isolation of Genomic DNA. Genomic DNA was extracted from peripheral leucocytes in $5 \mathrm{ml}$ blood using phenol-chloroform followed by ethanol precipitation (Sambrook et al., 1989).

Determination of the NAT2 Genotype. To amplify the 559 bp NAT2 genomic sequence containing the polymorphic site near the $3^{\prime}$ end of the coding region (nt803), sense (5') TGACGGCAGGAATTACATTGTC (nt342-363) and antisense (3') ACACAAGGGTTTATTTTGTTCC (nt879-900) oligodeoxynucleotides were synthesized by the Cycione Plus DNA Synthesizer (Milligen/Biosearch, Burlington, MA). The PCR mixture contained $100 \mathrm{ng}$ genomic DNA, 5 pmol of each oligonucleotide primer, dNTPs (each at $0.2 \mathrm{~mm}$ ), $10 \mathrm{~mm}$ Tris- $\mathrm{HCl}\left(\mathrm{pH} 8.8\right.$ at $25^{\circ} \mathrm{C}$ ), $1.5 \mathrm{mM} \mathrm{MgCl}_{2}, 50 \mathrm{~mm} \mathrm{KCl}, 0.1 \%$ Triton X-100, and 0.9 unit Taq DNA polymerase (Wako, Osaka) in a total volume of $10 \mu \mathrm{l}$. The mixture was incubated for $5 \mathrm{~min}$ at $94^{\circ} \mathrm{C}$ to denature the genomic DNA, annealed for $50 \mathrm{sec}$ at $55^{\circ} \mathrm{C}$, and extended for $50 \mathrm{sec}$ at $65^{\circ} \mathrm{C}$. Each cycle of amplification was started by denaturing the DNA at $94^{\circ} \mathrm{C}$ for $50 \mathrm{sec}$, and the final extension period was for $7 \mathrm{~min}$ at $72^{\circ} \mathrm{C}$. Twenty-five cycles of amplification were performed using a programmable heat block (Astec PC-700, Fukuoka). After amplification, a mixture of 5 units of BamHI, Asp 718 (isoschizomer of KpnI) and TaqI were added to the PCR product $(10 \mu l)$ directly. The mixture was incubated at $37^{\circ} \mathrm{C}$ for $3 \mathrm{hr}$ and then incubated 
at $65^{\circ} \mathrm{C}$ for $1 \mathrm{hr}$. The digested PCR products $(5 \mu \mathrm{l})$ were electrophoresed at 7.7 $\mathrm{V} / \mathrm{cm}$ for $60 \mathrm{~min}$ on agarose gel $(3 \%$ agarose $+1.5 \%$ Nusieve GTG agarose (FMC Bioproducts, Rockland, ME) containing $0.5 \times \mathrm{TBE}(1 \times \mathrm{TBE}=90 \mathrm{~mm}$ Tris $/ 90$ mM boric acid/2 mM EDTA) and ethidium bromide.

Genotyping of NAT2 using a hair root as DNA source. A hair root, instead of extracted leucocyte DNA, was added into $10 \mu$ PCR mixture without extraction of DNA. PCR cycle was increased to thirty, but other conditions were unchanged.

\section{RESULTS}

Figure 1 shows that the $4 N A T 2$ alleles have the different restriction maps, specifically, TaqI, Asp718, and BamHI have different sites on each allele. Am-

NAT 1
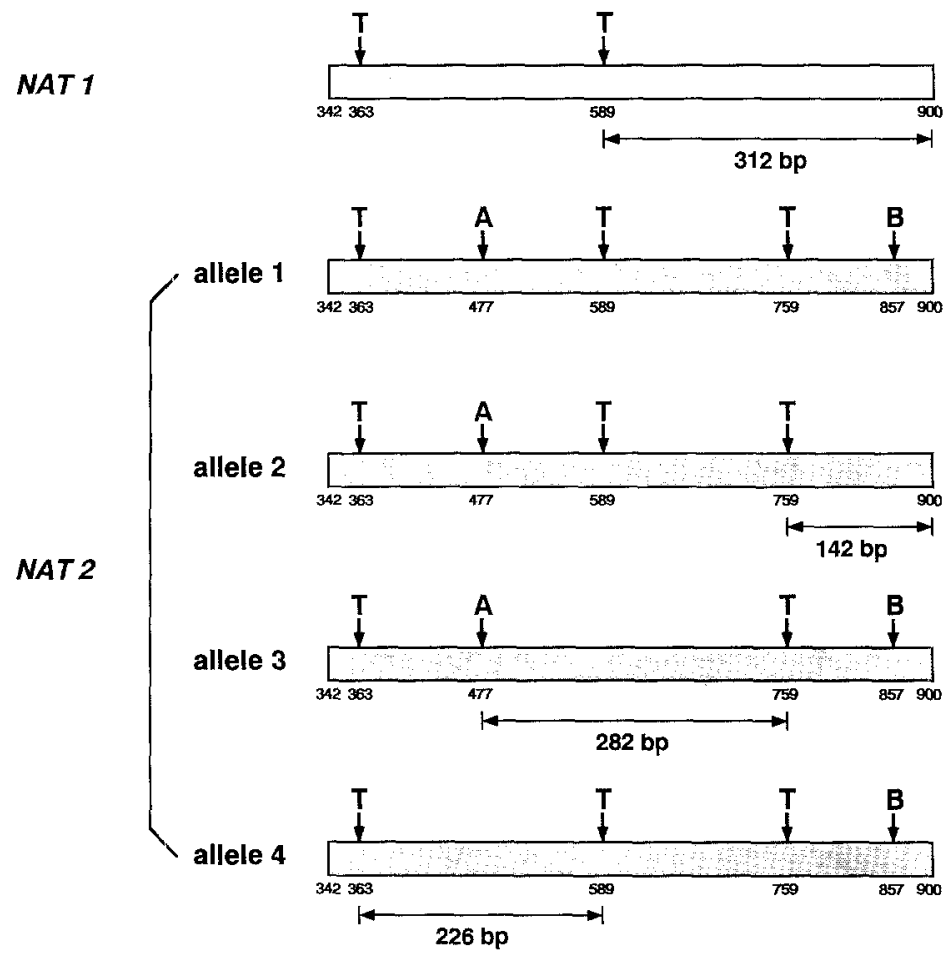

: amplified DNA fragment

Restriction enzyme site : $\mathrm{A}=A \operatorname{sp} 718, \mathrm{~T}=\operatorname{Taq} \mathrm{I}, \mathrm{B}=\operatorname{Bam} \mathrm{HI}$

Fig. 1. Restriction enzyme sites of $N A T 1$ and of 4 types of $N A T 2$ alleles. Shadowed bars illustrate the 559 bp DNA fragment (nt342-900) of $N A T 2$ amplified by PCR, and open bar the corresponding region of NATI. NATI structure was cited from the articles of Deguchi (1992). Under the bars, nucleotide numbers are indicated. The arrows under DNA fragments of $N A T 2$ denote the specific bands for allele 2, 3 , and 4. 
plification of the NAT2 genomic fragment with sense and antisense primers resulted in the formation of a $559 \mathrm{bp}$ fragment from $\mathrm{nt} 342$ to 900 which includes the RFLP. The figure shows that PCR products would have to be cleaved with TaqI, BamHI, and Asp718 to determine the types of $N A T 2$ alleles. Except for allele 1, specific bands for each allele could be easily recognized. For example, the presence of a $142 \mathrm{bp}$ band ( $\operatorname{Taq}^{759}$ site to $3^{\prime}$ amplified terminal. Superscript number means actual cutting site of restriction enzyme) would signify allele 2, a 282 bp band (Asp718477 site to $\operatorname{Taq}^{759}$ site) for allele 3 , and a 226 bp band ( $T a q I^{363}$ site to $T a q I^{589}$ site) for allele 4. If monomorphic NAT is amplified, a 312 bp band ( $T a q l^{589}$ to $3^{\prime}$ terminal) would emerge.

The electrophorestic pattern of PCR-based RFLP is shown in Fig. 2. We detected ten genotypes expected to appear from a combination of the 4 alleles; the genotype of allele $4 / 4$ was made artificially from the allele $1 / 4$ sample because the allele $4 / 4$ was not found in our Japanese DNA samples. The phenotypes corresponding to the genotypes were indicated; rapid acetylator (the genotype of allele $1 / 1$ ), intermediate acetylators (the genotypes of the pairs of allele 1 and the other allele) and slow acetylators (the genotypes of the combination of allele 2, 3, and 4). The heterozygotes for allele 1 were distinguished from the homozygotes of allele 2, 3, or 4 by the pattern of non-specific bands. A 312 bp band did not emerge. We also determined NAT2 genotyping using a hair root from 12 individuals

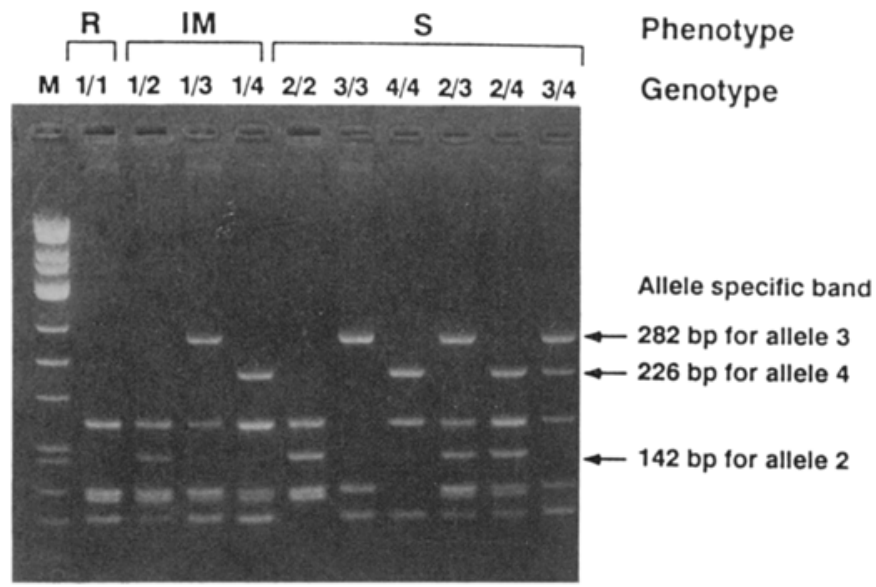

Fig. 2. The electrophoretic patterns of genotyping of $N A T 2$ by a PCR-based RFLP. A 559 bp $N A T 2$ genomic sequence (nt342-900) containing the polymorphic site near the $3^{\prime}$ end of the coding region (nt803) was amplified. PCR products were digested with BamHI, Asp 718 and TaqI, and separated on $3 \%$ agarose $+1.5 \%$ Nusieve GTG containing ethidium bromide. Allele $4 / 4$ was prepared artificially from allele $1 / 4$ by digestion with $A s p 718$ after amplification. Phenotypes shown in the figure mean acetylator status predicted from genotypes. R, rapid acetylator; IM, intermedate acetylator; $\mathrm{S}$, slow acetylator; $\mathrm{M}$, phaiX DNA markers digested with Hinf I. 
as genomic DNA source. NAT2 genotype could be determined in ten, but not in 2 samples because their DNA were not amplified (data not shown).

\section{DISCUSSION}

We have developed a NAT2 genotyping method using a PCR-based RFLP. Recently we published a report using a Southern blot analysis for genotyping (Mashimo et al., 1992). However, the PCR-based genotyping of NAT2 seems superior to the Southern blot analysis because the PCR doesn't need radioactive materials and it takes only one day to make a PCR mixture and to take an UV irradiated photograph.

Blum et al. (1991) distinguished 4 types of NAT2 using separate PCRs with three sets of allele specific primers specific to each mutation site. In the present study, we have used only one set of primers which amplifies all mutation sites since those sites are included in the recognition site of Asp718, BamHI, and TaqI. Hickman and Sim (1991) also distinguished NAT2 using the PCR with two sets of primers, and adopted three separate restriction enzyme digestions of the amplified products. In their study the Hincll digestion was necessary to confirm that the NAT2 had been amplified. In contrast with their study, our primers were designed to anneal to a less homologous region on NAT1 which codes for the NAT1 protein. Although NAT2 is highly homologous to NAT1 (Blum et al., 1990), the NAT1 specific band was not identified in our electrophoresis. Our method included successive restriction enzyme digestions without changing the reaction buffer. Since these restriction enzymes worked only moderately in the Taq DNA polymerase buffer, we added an excess amount of enzymes. Even when the incubation time was prolonged to one day, the enzymes cut no other site than the correct recognition site. We could determine the $N A T 2$ genotype by agarose electrophoresis using only one lane per one genomic DNA sample. This method allows us to determine the NAT2 genotypes rapidly, easily, and reliably. We applied this method to genotype 234 colorectal cancer patients without any trouble (to be submitted).

This method also worked when a hair root was used as genomic DNA source. Thomson et al. (1992) reported the superiority of the hair root as the DNA source for PCR. This method sometimes didn't work for an unknown reason, perhaps one trouble is caused by the amount of tissue attached to the hair root. When pupolation study of $N A T 2$ polymorphism is done, a hair root would be effective DNA source for genotyping.

Acknowledgments We are grateful to Dr. J. Miller and Mr. Perry Seto for critically reading the manuscript.

The work was partly supported by grants for Specific Disease from the Ministry of Health and Welfare of Japan. 


\section{REFERENCES}

Blum M, Demierre A, Grant DM, Heim M, Meyer UA (1991): Molecular mechanism of slow acetylation on drugs and carcinogens in humans. Proc Natl Acad Sci USA 88: 5237-5241

Blum M, Grant DM, McBride W, Heim M, Meyer UA (1990): Human arylamine $N$-acetyltransferase genes: Isolation, chromosomal localization, and functional expression. DNA Cell Biol 9: 193-203

Deguchi T, Mashimo M, Suzuki T (1990): Correlation between acetylator phenotypes and genotypes of polymorphic arylamine $N$-acetyltransferase in human liver. J Biol Chem 265: 1275712760

Deguchi T (1992): Sequences and expression of alleles of polymorphic arylamine $N$-acetyltransferase of human liver. J Biol Chem 267: 18140-18147

Evans DAP (1989): $N$-Acetyltransferase. Pharmacol Ther 42: 157-234

Grant DM, Blum M, Beer M, Meyer UA (1991): Monomorphic and polymorphic human arylamine $\mathrm{N}$-acetyltransferases: A comparison of liver isozymes and expressed products of two cloned gene. Mol Pharmacol 39: 184-191

Hickman D, Sim E (1991): $N$-Acetyltransferase polymorphism-Comparison of phenotype and genotype in humans. Biochem Pharmacol 42: 1007-1014

Ilett KF, David BM, Detchon P, Castleden WM, Kwa R (1987): Acetylation phenotype in colorectal carcinoma. Cancer Res 7: 1466-1469

Lang NP, Chu DZJ, Hunter CF, Kendall DC, Flammang TS, Kadlubar FF (1986): Role of aromatic amine acetyltransferase in human colorectal cancer. Arch Surg 121: 1259-1261

Mashimo M, Suzuki T, Abe M, Deguchi T (1992): Molecular genotyping of $N$-acetylation polymorphism to predict phenotype. Hum Genet 90: 139-143

Mommsen S, Aagaard J (1986): Susceptibility in urinary bladder cancer: Acetyltransferase phenotypes and related risk factors. Cancer Lett 32: 199-205

Ohsako S, Deguchi T (1990): Cloning and expression of cDNAs for polymorphic and monomorphic arylamine $N$-acetyltransferases from human liver. J Biol Chem 265: 4630-4634

Sambrook J, Fritsch EE, Maniatis T (1989): Molecular cloning. A laboratory manual, 2nd ed., Cold Spring Harbor Laboratory Press, New York, pp 9.16-9.19

Thomson DM, Brown NN, Clague AE (1992): Routine use of hair root or buccal swab specimens for PCR analysis: Advantages over using blood. Clin Chim Acta 207: 169-174

Vatsis KP, Martell KJ, Weber WW (1991): Diverse point mutations in the human gene for polymorphic $N$-acetyltransferase. Proc Natl Acad Sci USA. 88: 6333-6337

Weber WW, Hein DW (1985): $N$-Acetylation pharmacogenetics. Pharmacol Rev 37: 25-79 